\title{
Assessment process in the delimitation of historic urban landscape of Algiers by AHP
}

\begin{abstract}
This research paper covers the way in which landscape delimitation is carried out in a historic urban area context. Landscape delimitation, in this case, explores the relationship between landscape considerations in the urban and heritage planning system in Algeria. The characterisation of the historic urban landscape is challenged by various types of values. The landscape assessment of the central urban historic area of Algiers was focused on its beauty configuration using the AHP multi-criteria method, supported by values obtained through GIS. Various delimitation alternatives of the historical urban landscape are assessed. Distinctive landscapes emerge, moving away from the original historic urban landscape, which is strictly related to the context of the casbah. Spatial landscape delimitation is the means by which the connecting values of the landscape and their interconnections are managed by monitoring problems of fragmentation and ensuring their interaction at the different boundaries. Urban planning must necessarily incorporate landscapes boundaries into the decision-making processes for the conservation of value connections and managing its beauty configuration.
\end{abstract}

Keywords

Historic urban landscape - landscape assessment • decision process • criteria SIG • landscape delimitation

(C) University of Warsaw - Faculty of Geography and Regional Studies

\author{
Boukratem Oumelkheir $\mathbb{C}^{1,2}$ \\ Djelal Nadia $\mathbb{C}^{1,2}$ \\ 'EPAU, Polytechnic School of Architecture and Urbanism, \\ Algiers, Algeria \\ 'Laboratory City Urbanism Sustainable Development \\ (VUDD) EPAU; Algiers, Algeria \\ e-mail: faridaboukratem@yahoo.fr \\ e-mail: Nadiadjelal@gmail.com \\ Received: 20 February 2020 \\ Accepted: 24 October 2020
}

Introduction

Landscape protection has been enormously influenced by the evolution of its various consecrations and meanings (Michael Jacob 2004), and by its dimensions, characteristics, and perceptions (Cassatella \& Voghera 2011). The overlap between natural and cultural sites is often confused with the concept of cultural heritage according to territorial, environmental, and urban considerations (Getty Conservation Institute 2009). The cultural interpretations highlight how landscape has become of huge interest in the conservation development of cultural and natural heritage (Fitri et al. 2015). The protection of the landscape guides the reflections of the values it expresses, although the European convention generalizes the principle of recognition of remarkable or degraded landscapes, but the conditions of protection only apply to natural and heritage configurations (Scolozzi et al. 2012).

Protection in protected landscapes targets the integrity of the landscape and the maintenance of the authenticity of the cultural components (Phillips \& Union 2002), while in cultural landscapes the recognition of outstanding universal value is fundamental to the selection of sites for UNESCO conservation policy. The persistence of the cultural process of the value of authenticity in protected landscape areas originates in the protected area's management; so, the area to be protected is linked to the heritage values attributed to its historical entity, in which meanings contribute to its definition (Getty Conservation Institute 2009). Obviously, the issue of landscape delimitation at different geographical scales is very important for landscape structure identification (Richling et al. 2013).
Within the category of the cultural landscape sites listed as UNESCO recommendations - the selection of cultural landscape areas inscribed on the UNESCO World Heritage List for monitoring and evaluation is conditioned by a spatial delimitation of the territory that encompasses the characteristics of the settlement and reflects the interactions between man and his natural environment. Thus, the social and spiritual values resulting from the evolution of human settlements over time, under the influence of physical constraints, traditions, and cultural aspirations, have remained intact.

Although, according to Ingold, the segmentation of the landscape does not exist; and the notion of limit is elusive because the present contains the past and the future within itself (Ingold 1993). Therefore, various attitudes can be adopted (Dhingra et al. 2017) in human interactions, from which other values can emerge according to continuous evolution (Layton et al. 2003). This constitutes an important issue for landscape characteristics, and that is why this paper explores the way in which the landscape is delimited in a historical urban area context. UNESCO's implementation of the historic urban landscape approach (Gravagnuolo \& Girard 2017) in the management of historic cities and in urban planning (Gabrielli 2008; Van Oers 2010), conceptualizes it as a system of organization, which combines natural and historical elements in shaping the state of things that are distinguished by the sum of their characteristics and by the consolidation of their relationships (Ingold 1993; Voghera 2011; Volpiano 2011). 
The universal recommendations by UNESCO and ICOMOS have been analysed for their contribution to the landscape, the indications of which relate more to the values that affect the landscape than heritage. By comparing the values attributed to the landscape to those of heritage, relevant values emerge in the delimitation of the historic urban landscape (Jokilehto 2010); these are: aesthetic value, historic value, and grouping value.

The focus of this paper is to consider the aggregated historical entities of the central historic urban area of Algiers as a system of components and, therefore, as a historical urban landscape. The central historic urban area is not a designated historic urban landscape and is therefore not protected by law. The task of identifying landscapes cannot be well-defined in a direct way because the balance between the sites' types of values and attributions raises questions, and requires different approaches and levels of evaluation (Finotto 2011; Bottero 2011).

\section{Framework of the case study}

The framework that is in place for the selection of landscape sites in Algeria does not instrumentalise the landscape as a territorial and environmental strategic planning domain, but rather as a component in specifying the coastal zones and protected areas (SNAT 2008; SDZAH 2008; SDAAM 2010; PDAU 2010; PDAU 2015; PIPPA 2012). The exploration followed the delimitations applied to heritage and landscape, and their incorporation into urban planning instruments.

The manipulation of the landscape within urban planning emanates from the compositional aspect of certain places, and not as a totalitarian concept in and of itself. The historic urban landscape of Algiers is seen as a whole because it is composed of two different historic entities, but due to their characteristics they have generated relations and perceptions (Peano et al. 2011) in very specific contexts between land and sea (Federico Cresti 1996). Algiers seems to be engaged in confronting multiple risks due to the acceleration of urban growth and the importance of the economic dynamism taking place there. Thus, its central historic urban area (Fig 1.) is becoming increasingly fragile and exposed to the risk of the transformation and degradation (de Noronha Vaz et al. 2012; Luo et al. 2018) of its environment; of its environment; of its urban fabrics and buildings (Béguin, Baudez et al. 1983), due largely to pollution; to the contamination of the marine environment (PAC 2006) resulting from the state of land use and the multiplication of port functions. The central, historic urban area of Algiers is a major issue as a landscape as a whole whose historical entities enable a special connectivity (Bergsten \& Zetterberg 2013).

\section{Methodology}

The highlight of this research paper is the process of characterising and delimiting (Dobson 2012) the historical urban landscape configuration (Fig 2) of the central, historic urban area of Algiers. The assessment of landscape delimitation in Algiers' urban context was produced by applying a beauty value (as a grouping value), by exploring the relevant levels of the attribution of landscape and heritage based on combined elements, which together expresses beauty (Forte et al. 2006; Tieskens et al. 2018).

The use of the Analytic Hierarch Process (AHP) (Saaty 1990; Saaty \& Vargas 2012) approach; recognised for its comparability criteria, qualitative characteristics, and exploration level is, in the context of the issues, well suited to the steps of hierarchical analysis used in defining landscape configuration.

The criteria were drawn from the data analysis of the heritage, the natural context of Algiers, and the historic urban fabric evolution, and were, therefore, combined in a systemic structure (Voghera 2011; Volpiano 2011; Zhang 2011).

After this they were formulated and organised in a hierarchical structure (Belton \& Stewart 2002). The data that generated the criteria were spatially mapped using GIS to visualize their structure and then determine the different delimitation alternatives. The assessment was about the criteria's effects on the delimitation of four alternative (Zetterberg et al. 2010) historical urban landscapes in Algiers.

The four alternatives were defined according to the contexts of their evolution: the first alternative concerned the first nucleus - the casbah, the second concerned the first evolution of the French city in the vicinity of the casbah, the third was defined in relation to the French fortifications, and the fourth alternative was the French city established on the heights of Algiers.

\section{Mapping using GIS}

The characteristics and historical data were transcribed from historical maps (Fig 3) and other ancient master urban planning documents (GURA 1963; PUD 1987) such as morphological and natural elements: maritime sites, coastal frontage, cliffs, and the morphology of the territory such as promontories, plateaus, and balconies (Fig 4).

From the analysis of the urban fabric, the identification of the typology of the first nucleus of the casbah (Missoum 2003; Nacib.Y, Icheboudene.L 2003) is clearly confirmed by its structure and its urban organisation, which are integrated into the morphological context of the hilly site that dominates the bay of Algiers. The recognition of land use is an important factor in the assessment of the landscape (Morehart \& Millhauser 2016) of Algiers as an economic capital city (Antrop 2004), which was, in the past, known as a big maritime city (Missoum 2003; Raverau 2007). Therefore, the formation of the central, historic urban area has raised up mechanisms related to the natural beauty of the site, the historicity of spaces (Chouquer 2000), and the concentration of places for decisions and activities (Fig 5). The data relating to the heritage safeguarding process was mapped using GIS (Dhingra et al. 2017) - sites and monuments classified as world heritage, the inventory of buildings for classification and the safeguard sector (PPMVSS 2007) - which permitted the concentration of heritage components to be observed, and the boundaries of the safeguarding sector and the boundaries of the classified sites to be distinguished (Fig 6). Furthermore, the divergence of the boundaries between the classified perimeter of the casbah and those of the casbah's safeguarded area raises problems with spatial use and the need to approach the entities together as a historical urban centrality (Dhingra et al. 2017).

The more characteristics identified for the different periods of evolution of Algiers the more informed we are about the interference between the casbah and the colonial cities, which highlights the places course of occupation and establishment (Lespès 1930; Çelik 1997). Accordingly, the colonial city was influenced by the traditional one, but in their coupled entities they express exceptional beauty (Fig 7). The formulation for the criteria and sub-criteria (Table 1) focused on the significant values and their distributions across locations (Ruiz-Frau et al. 2011).

\section{Results}

The AHP process was applied to the Algiers data for five criteria and twenty-two sub-criteria, and applied to the four alternatives for historical urban landscape delimitation. The first phase of the process, i.e., the weights and values of the criteria and sub-criteria, were calculated according to the principle of the application of paired comparison to each level of the hierarchy's matrix that indicated the judgments (Saaty 1990) and then derived the measurement. The normalisation of values for each criteria's category were produced by using the priority vector (Table 2). Then the $\lambda$ max value was calculated from the combination of a matrix of $n$ elements, the value of the priority vector, and the application of the formula IC $=\frac{(\lambda \max -1)}{(\mathrm{n}-1)} ; \mathrm{CR} \frac{C I}{R I}$. 


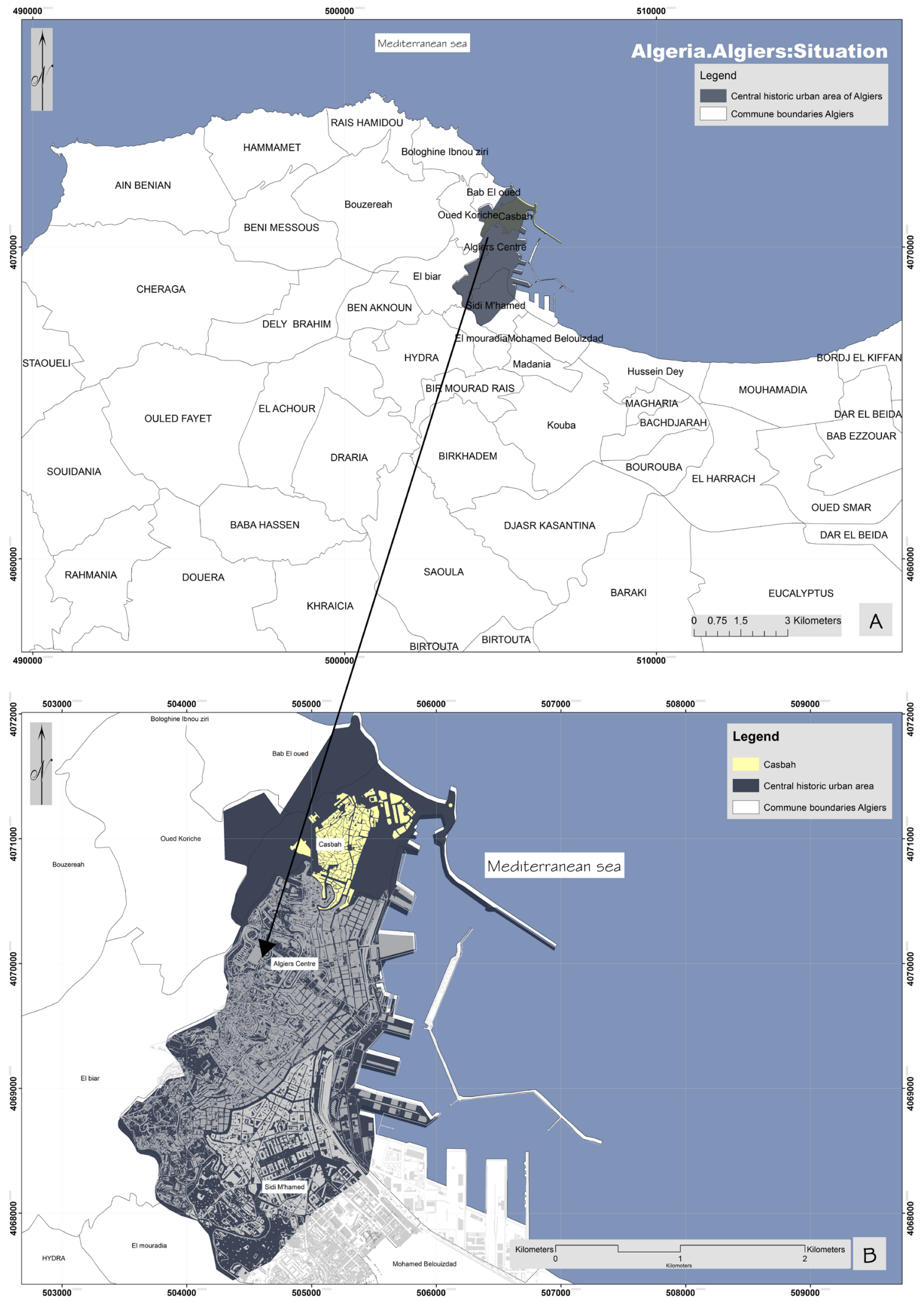

Figure 1. Map of the location of the central, historic urban area of Algiers.

Source: own study 


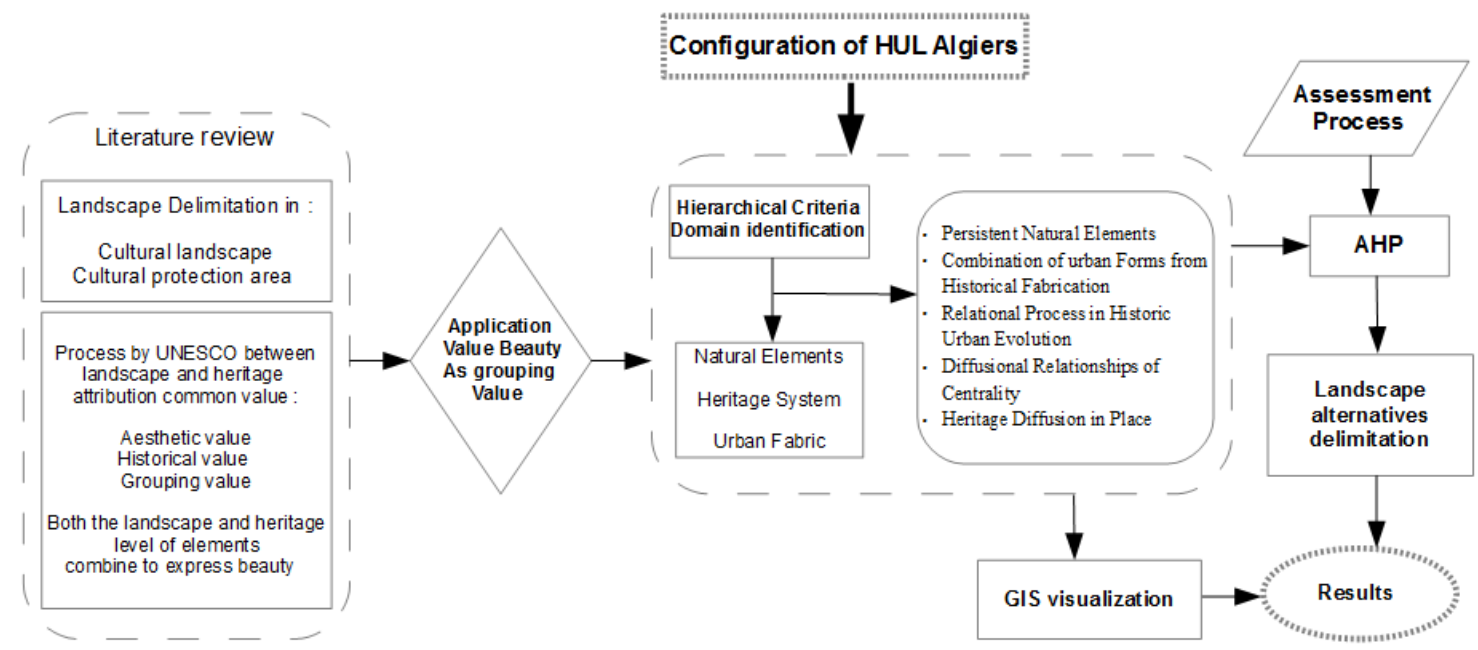

Figure 2. The conceptual framework for the process of delimitation of landscape in the historical urban area context. Source: own study

The principle of judgment is consistent when CR is nearest to 0 ; if its value is greater than 10 percent the evaluation should be reshaped. The calculation of the comparison vector at the level of the criteria gave fairly high distinctive values: 0.54 for the criterion for the site's beauty, 0.213 for the configuration of the relational system criterion, and 0.128 represents the criterion of configuration for urban beauty. However, the lower values were those of the historical centrality configuration criterion, with a value of 0.067 , and the heritage system configuration criterion with a vector of 0.052 . The judgments for the delimitation alternatives under different criteria were produced by the different values in each landscape configuration (Table 3). The performance of the criteria in each delimitation alternative was highlighted by different values: P1 (medina landscape) by 0.603, P2 (colonial city landscape within the protection walls) by 0.251 , P3 (colonial landscape historic city centrality) by 0.060 , and P4 (colonial city landscape in the evolution on the heights) was determined by 0.090 .

The value of the criterion and its classification in the configuration of the different landscape alternatives generated different categories of performance value. We noted three categories of numerical values in the casbah city (P1) (Fig 8): the best performing were two sub-criteria, the maritime site with a value of 7.4 percent and the bay configuration with a value of 6.2 percent; the second category included thirteen sub-criteria, indicating values between 5 percent and 1 percent; and in the fourth category, seven sub-criteria with values between 1 percent and 0 . In the colonial town (P2), within the enclosure (Fig 9), three categories of values were noted: the best performing with the value of 7.4 percent concerns the maritime site subcriterion; the second category concerns seven sub-criteria with values between 3 percent and 1 percent; and the third category, with fourteen sub-criteria, had values between 1 percent and 0 . The Algiers' historical centrality (P3) (Fig 10) revealed three categories of values: the best performing, with a value of 1.8 percent concerned the maritime site sub-criterion; the second category, with values between 1 percent and 0 grouping together sixteen sub-criteria, and the third category with five sub-criteria had a value of 0 performance. The most particular was the alternative evolution of Algiers on the heights (P4) (Fig 11) with results classified into two categories that were less than 3 percent. The values of the criteria and their rankings for the landscape configuration of the evolution of P4 on the heights indicated two categories of values, the first of which was represented by a value of less than $3 \%$ and included only the sub-criterion of the maritime site; while the second was made up of twenty-one subcriteria, reflecting a category of values less than $1 \%$ but greater than zero. The contribution of the criteria in the delimitation of HUL Algiers (Fig 12) was observed from the performance of the highly distinguished maritime sub-criterion site under the Site Beauty criterion with a numerical value of 30 percent; the second category of sub-criteria presented values between 5 percent and 10 percent, and concerned the contribution of the fifth sub-criterion under the Site Beauty criterion as well as the performance sub-criteria under the Urban Beauty criterion configuration and the Relational System configuration.

The third category of interval values, between 5 percent and 2.5 percent, related to the fourth sub-criterion within the Relational System configuration criteria, and one sub criterion from the Historic Centrality Configuration; while, lastly, the fourth category concerned twelve sub-criteria: one from Site Beauty, two from the Urban Beauty configuration, three sub-criteria from the Relational System configuration, two criteria from the configuration of Historic Centrality, and all the sub-criteria from the configuration of the Heritage System.

Thus the landscape delimitation for the central historic urban area presents the following results (Fig 13): p1 (Landscape Casbah city) with a value of 60 percent, P2 (Landscape colonial city within protection walls) with a value of 25 percent, P3 (Landscape colonial city historical centrality) with a value of 6 percent, and P4 (Landscape colonial city higher evolution) with a value of 9 percent.

\section{Discussion}

Our paper presents some major findings. First, the use of a criteria and sub-criteria system in applying the configuration of beauty as a grouping value for historic urban entities has brought about certain performances in the exploration of a landscape configuration in a historic urban area. The task of studying the contribution of each sub-criteria and determining their ranking for each delimitation, has allowed the performance of each criteria to be explored, as well as the importance of sub-criteria values, which takes into account the types of connections in the landscape configuration. The distinction between the number of criteria and sub-criteria, as well as their categories, reveals their role, and which of them become decisive in the configuration of the grouping value. 




Figure 3. Map Historical Evolution of Algiers on Year 1880 location Source: based on map dating from 1880 


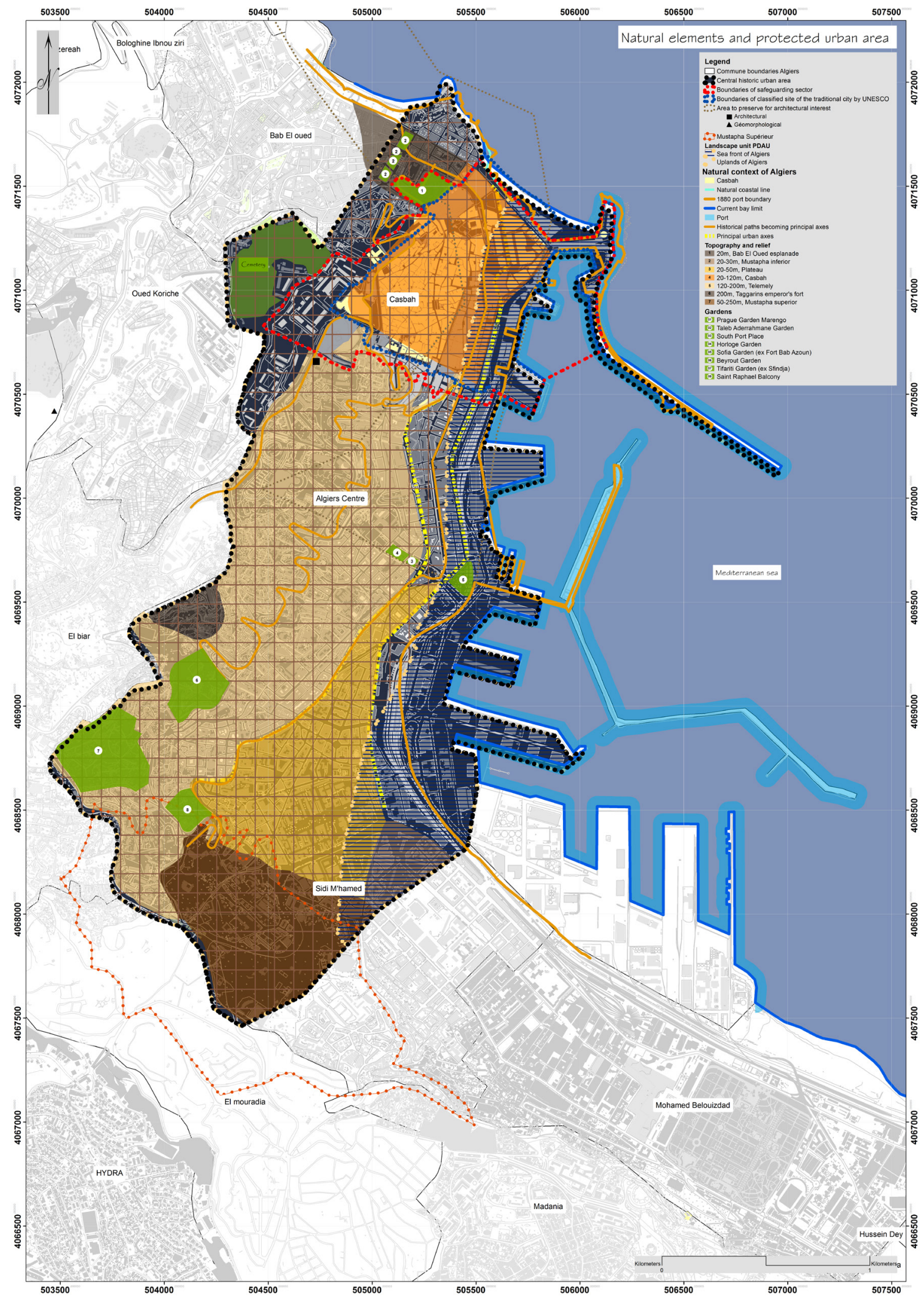

Figure 4. Map of natural elements in the central historic urban area of Algiers Source: own study 
MISCELLANEA GEOGRAPHICA - REGIONAL STUDIES ON DEVELOPMENT

Vol. $25 \cdot$ No. 2 - 2021 • pp. 110-126 • ISSN: 2084-6118 • DOI: 10.2478/mgrsd-2020-0053

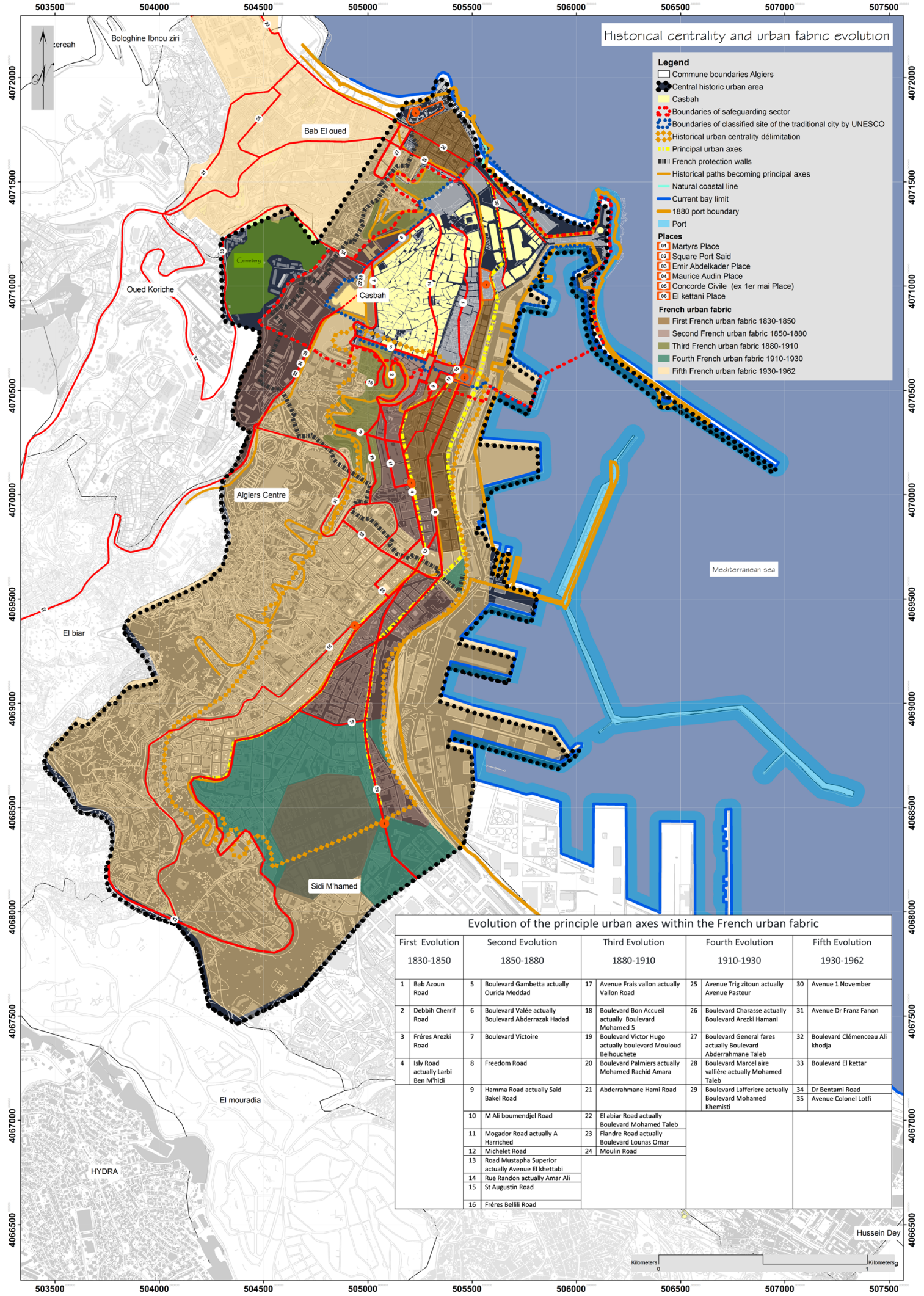

Figure 5. Map of historical centrality of Algiers

Source: own study 


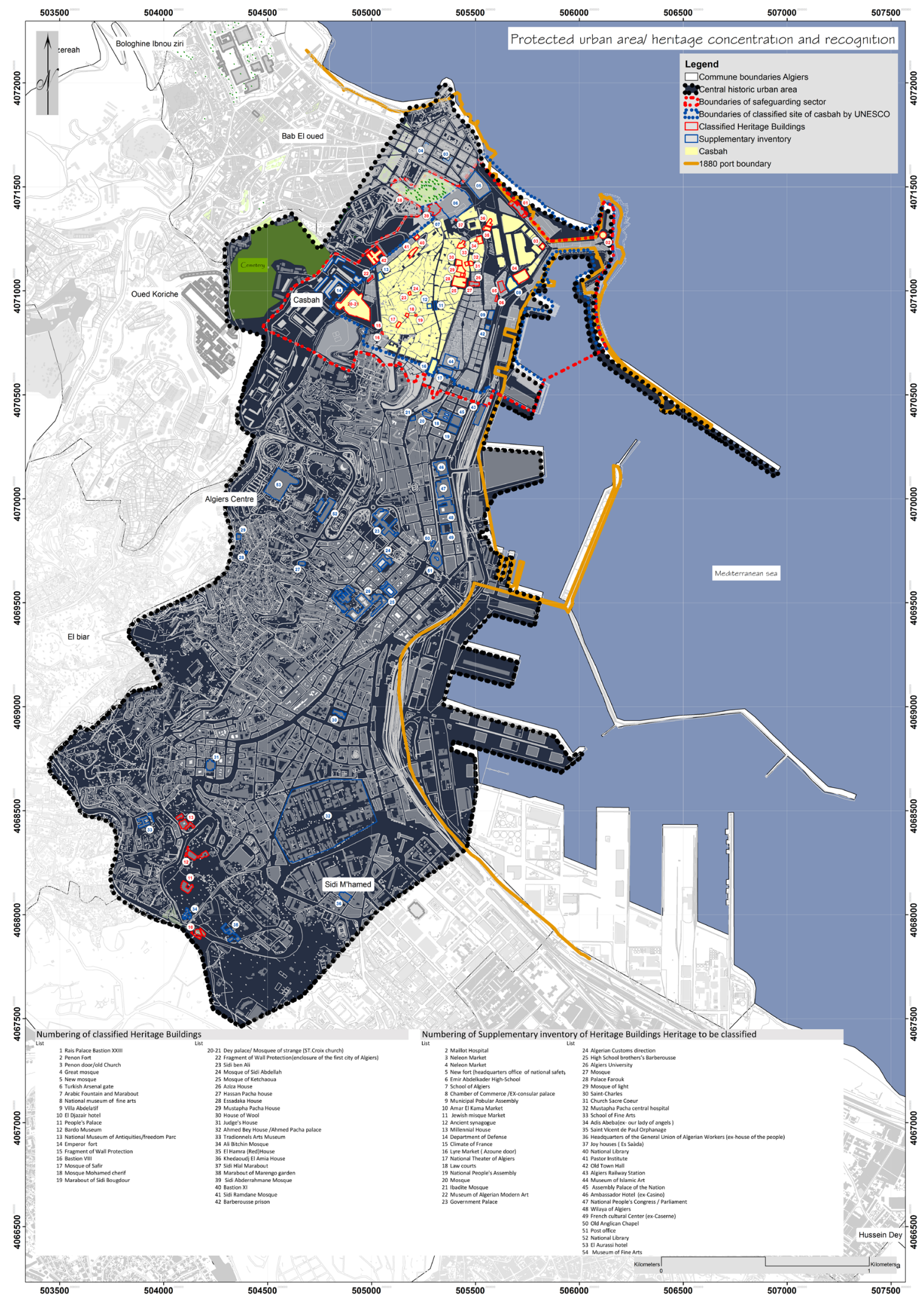

Figure 6. Map of heritage concentration and recognition in the central historic urban area of Algiers Source: own study based on information from PDAU Algiers 


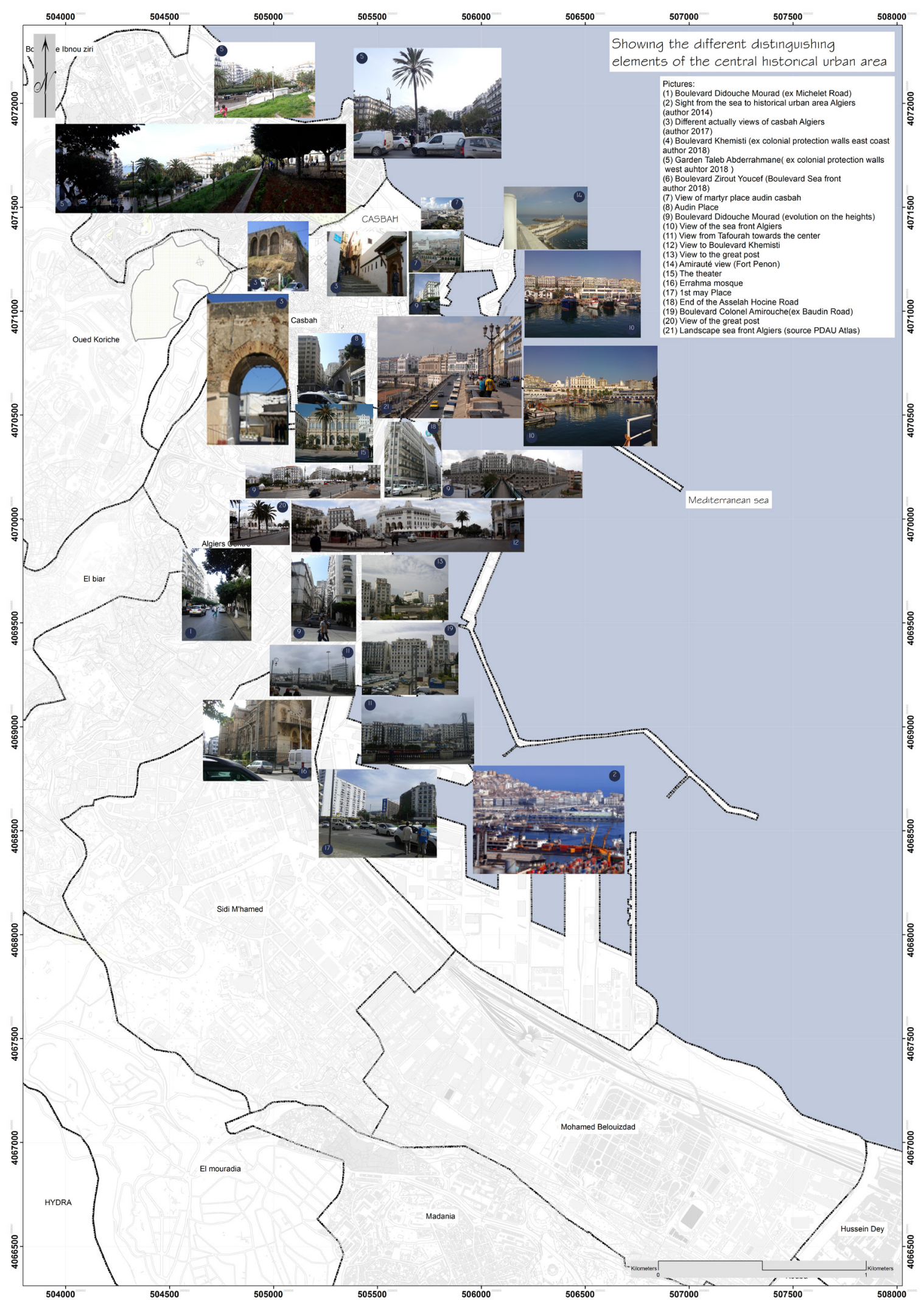

Figure 7. Map of distinguishing elements of the central historic urban area of Algiers.

Source: own study 
Table 1. Criteria and sub-criteria in the alternative delimitation of the historical urban landscape of Algiers

\begin{tabular}{|c|c|c|}
\hline Criteria & & Sub-criteria \\
\hline \multirow{5}{*}{$\begin{array}{l}\text { Site } \\
\text { Beauty }\end{array}$} & SC1 & Maritime site \\
\hline & SC2 & Bay configuration \\
\hline & SC3 & Port site \\
\hline & SC4 & Morphology and topography of the hilltop's relief (promontory, plateaus, amphitheatre) \\
\hline & SC5 & Physical and natural views of the bay \\
\hline \multirow{4}{*}{$\begin{array}{l}\text { Urban Beauty } \\
\text { Configuration }\end{array}$} & SC6 & Sharing the exceptionality of the beauty of the coastal boulevard \\
\hline & SC7 & Urban ensembles inclined against rugged land \\
\hline & SC8 & Gardens location \\
\hline & SC9 & Interdependence of the architectural dimension and the urban dimension \\
\hline \multirow{5}{*}{$\begin{array}{c}\text { Relational } \\
\text { System } \\
\text { Configuration }\end{array}$} & SC10 & Territorial structuration dating from the Roman period \\
\hline & SC11 & Interpenetration of the colonial city in the context of the medina \\
\hline & SC12 & Road extensions in relation to the medina, the sea, and the protective walls in the first phase \\
\hline & SC13 & Haussmann-style typology of urban axes in relation to the site and the sea in the second phase \\
\hline & SC14 & The structural spatial typology of links through public squares \\
\hline \multirow{4}{*}{$\begin{array}{c}\text { Historical } \\
\text { Centrality } \\
\text { Configuration }\end{array}$} & SC15 & Cultural heritage concentration in the casbah \\
\hline & SC16 & Concentration of urban spaces for centralizing activities \\
\hline & SC17 & Urban axes centralising city walks \\
\hline & SC18 & Persistence of commercial port activity and its development as an economic exchange centre \\
\hline \multirow{4}{*}{$\begin{array}{c}\text { Heritage } \\
\text { System } \\
\text { Configuration }\end{array}$} & SC19 & Universal heritage component of the traditional Algiers' casbah \\
\hline & SC20 & Safeguarding the casbah sector over an area of 105 ha (with protection bands) \\
\hline & SC21 & $\begin{array}{l}\text { Architectural typological diversity of landmark buildings belonging to the traditional city, and of public } \\
\text { buildings of the colonial city }\end{array}$ \\
\hline & SC22 & Concentration of heritage buildings with exemplary architectural and urban qualities from the nineteenth century \\
\hline
\end{tabular}

Source: own study

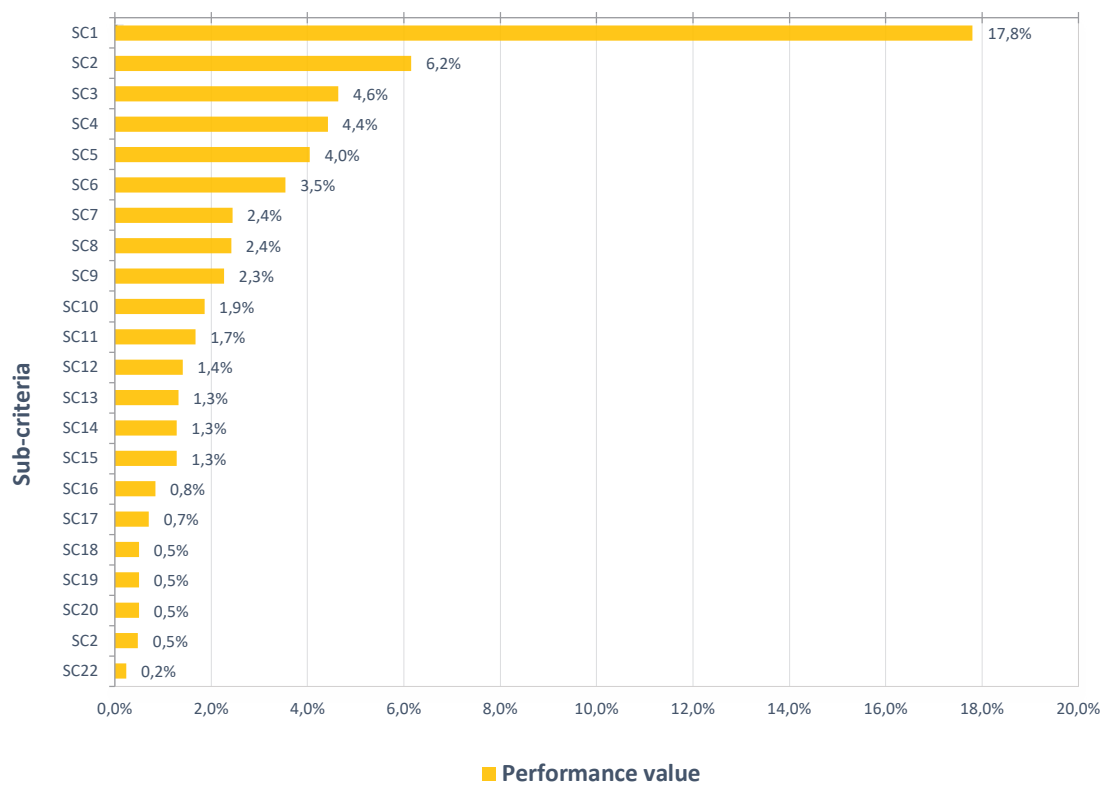

Figure 8. Criterion value ranking in the landscape configuration of the casbah Algiers (P1) Source: own study 
MISCELLANEA GEOGRAPHICA - REGIONAL STUDIES ON DEVELOPMENT

Vol. $25 \cdot$ No. $2 \cdot 2021 \cdot$ pp. 110-126 • ISSN: 2084-6118 • DOI: 10.2478/mgrsd-2020-0053

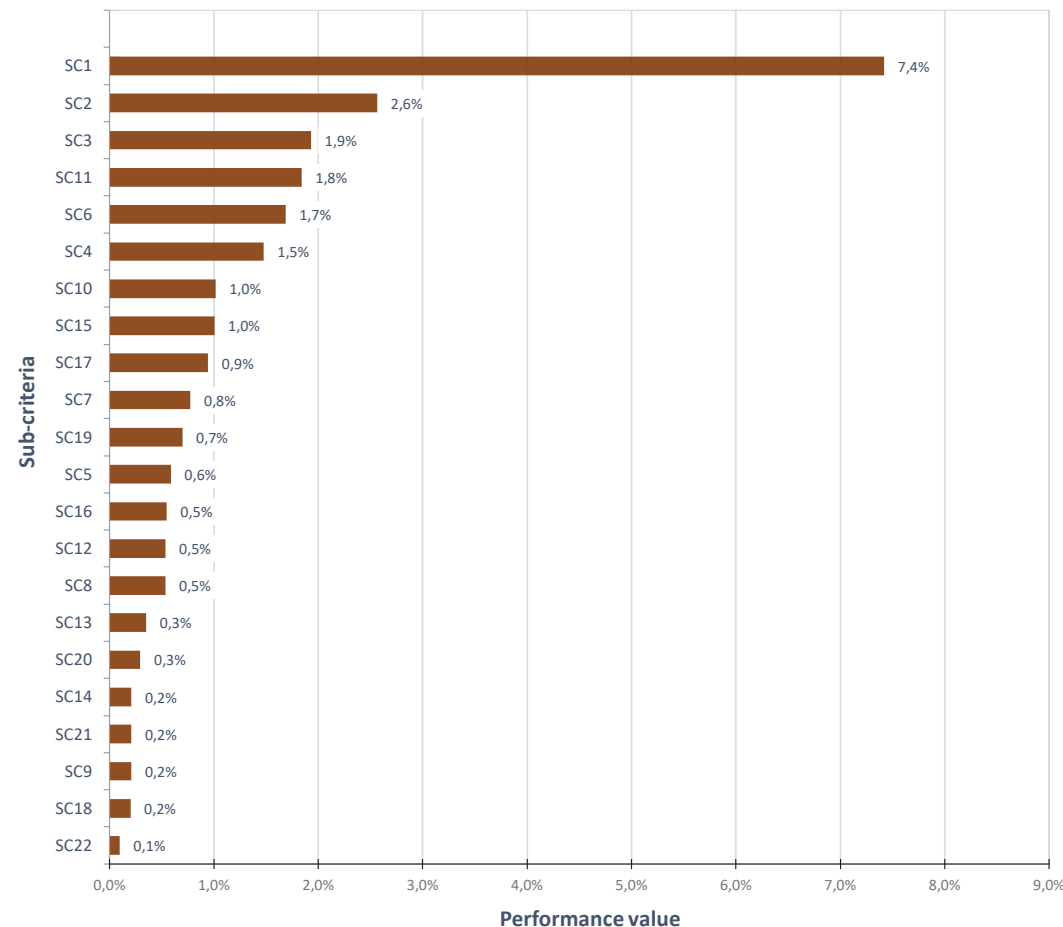

Figure 9. Criterion value ranking in the landscape configuration of the colonial city within the protection walls of Algiers (P2) Source: own study

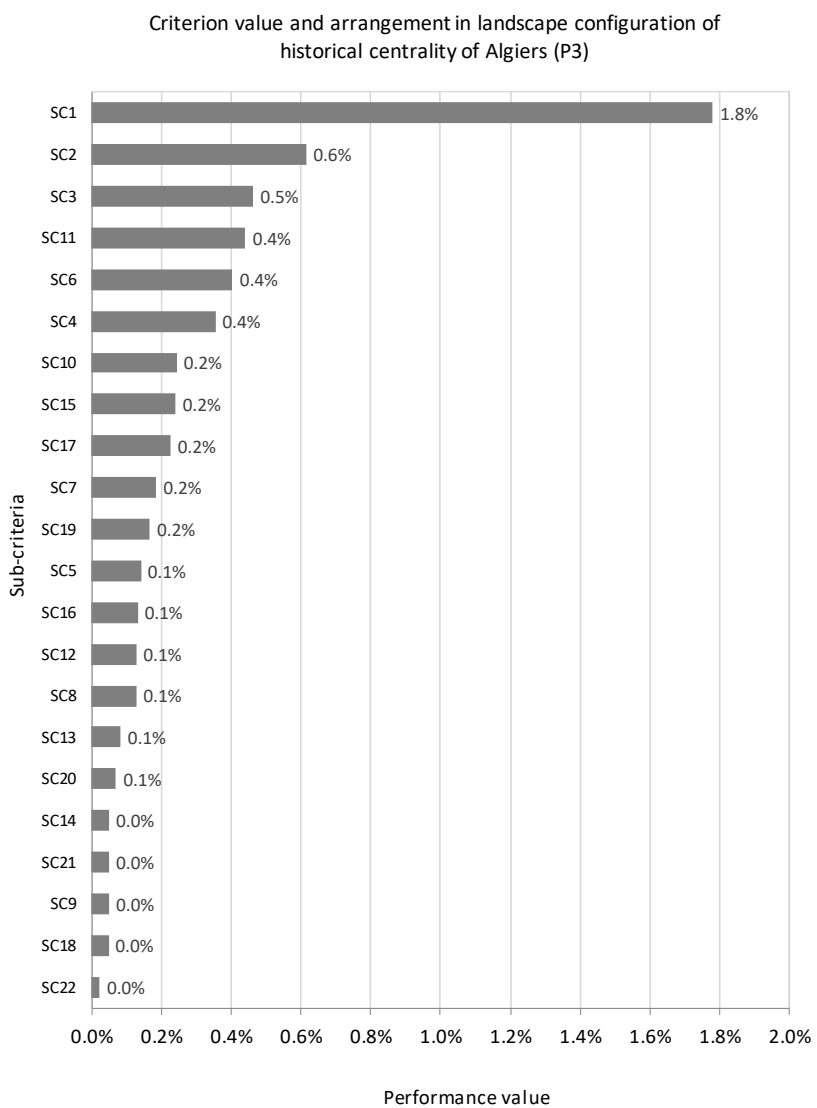

Figure 10. Criterion value ranking in the landscape configuration of the colonial city historical centrality of Algiers (P3) Source: own study 


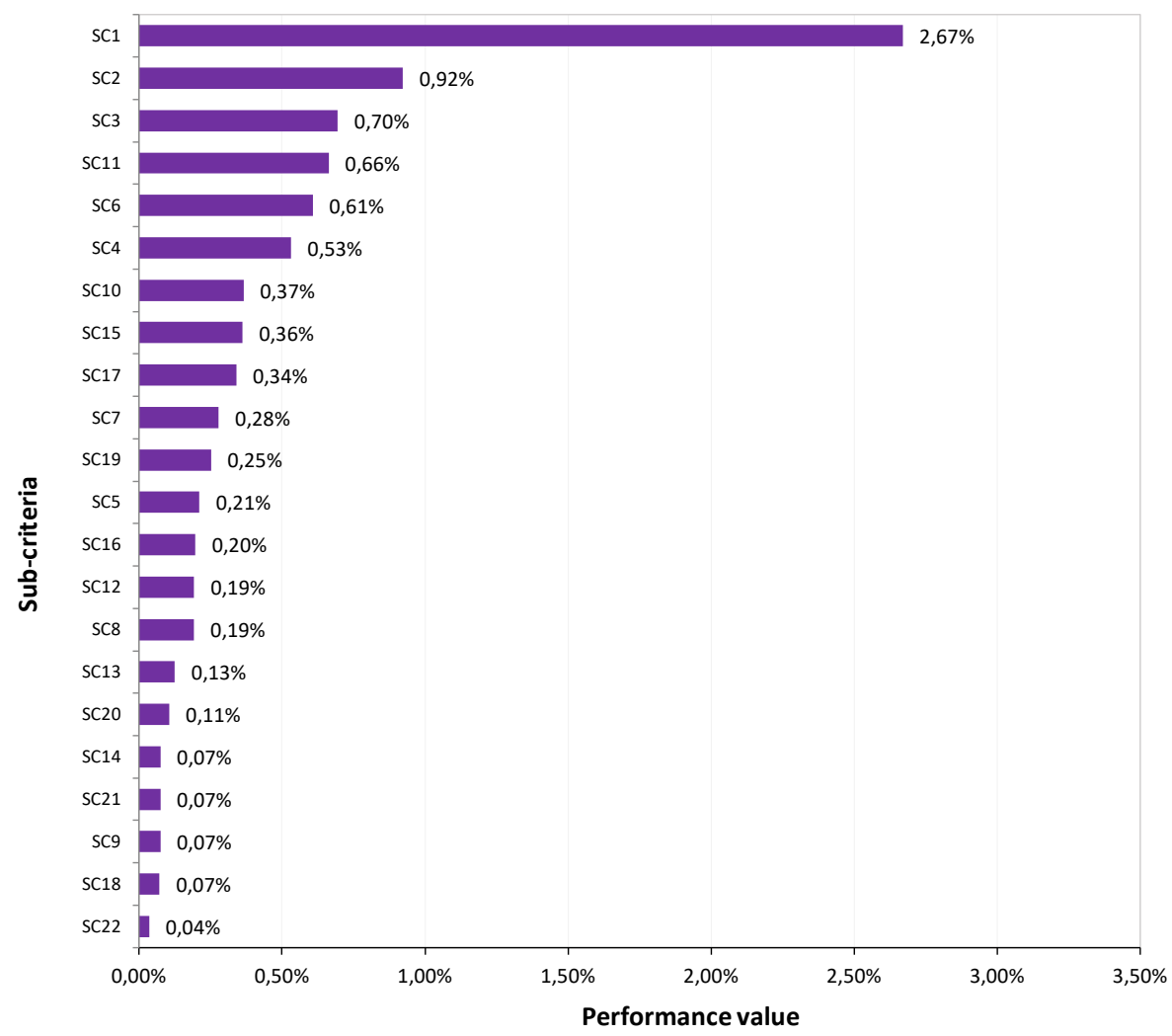

Figure 11. Criterion value ranking in the landscape configuration of the colonial city evolution of heights of Algiers (P4) Source: own study

Table 2. Pairwise comparison matrix criteria; level 1

\begin{tabular}{|c|c|c|c|c|c|c|}
\hline & $\begin{array}{c}\text { Site } \\
\text { Beauty }\end{array}$ & $\begin{array}{c}\text { Urban } \\
\text { Beauty configuration }\end{array}$ & $\begin{array}{l}\text { Relational System } \\
\text { configuration }\end{array}$ & $\begin{array}{l}\text { Historical } \\
\text { Centrality }\end{array}$ & $\begin{array}{c}\text { Heritage } \\
\text { System configuration }\end{array}$ & $\begin{array}{l}\text { Priority } \\
\text { Vector }\end{array}$ \\
\hline $\begin{array}{l}\text { Site } \\
\text { Beauty }\end{array}$ & 1 & $1 / 5$ & $1 / 5$ & $1 / 7$ & $1 / 7$ & 0.540 \\
\hline $\begin{array}{l}\text { Urban Beauty } \\
\text { configuration }\end{array}$ & 5 & 1 & 3 & $1 / 3$ & $1 / 3$ & 0.128 \\
\hline $\begin{array}{l}\text { Relational System } \\
\text { configuration }\end{array}$ & 5 & $1 / 3$ & 1 & $1 / 5$ & $1 / 3$ & 0.213 \\
\hline $\begin{array}{c}\text { Historical Centrality } \\
\text { configuration }\end{array}$ & 7 & 3 & 5 & 1 & $1 / 2$ & 0.067 \\
\hline $\begin{array}{l}\text { Heritage System } \\
\text { configuration }\end{array}$ & 7 & 3 & 3 & 2 & 1 & 0.052 \\
\hline \multicolumn{7}{|c|}{$\lambda_{\max }=5.358$} \\
\hline
\end{tabular}

Source: own study

Nineteen sub-criteria are significant in the alternative P1 (landscape of the medina), while fifteen are in P2 (landscape of the colonial city (surrounding walls)), six are in P4 (the colonial city (evolution of the heights)), and only three in P3 (historical centrality). Then the beauty of the site, followed by the relational system configuration, and then the urban beauty of the configuration, represent the most efficient criteria.
Distinctions affect the different types of landscapes. The alternatives for the delimitation of $\mathrm{P} 1$ and $\mathrm{P} 2$ tend to be proportional and take on the same distribution as the criteria scores. The alternatives for P3 and P4 are almost alike and are nearly indistinguishable.

The sub-criterion of the concentration of heritage buildings with exemplary architectural and urban qualities from 
MISCELLANEA GEOGRAPHICA - REGIONAL STUDIES ON DEVELOPMENT

Vol. $25 \cdot$ No. $2 \cdot 2021 \cdot$ pp. 110-126 • ISSN: 2084-6118 • DOI: 10.2478/mgrsd-2020-0053

Table 3. Performance sub-criteria in alternative delimitation of historical urban landscape of Algiers

\begin{tabular}{|c|c|c|c|c|c|c|c|c|c|c|c|c|c|c|c|c|c|c|c|c|c|c|c|c|}
\hline & & $\mathrm{SC} 1$ & $\mathrm{sc} 2$ & SC3 & SC4 & SC5 & SC6 & $\mathrm{SC} 7$ & SC8 & Sc9 & SC10 & SC11 & $\mathrm{SC} 12$ & $\mathrm{sc} 13$ & $\mathrm{SC} 14$ & SC15 & SC16 & SC17 & SC18 & Sc19 & SC20 & SC21 & SC22 & \\
\hline & & 0.297 & 0.103 & 0.077 & 0.059 & 0.023 & 0.067 & 0.031 & 0.021 & 0.008 & 0.041 & 0.074 & 0.021 & 0.014 & 0.008 & 0.040 & 0.022 & 0.038 & 0.008 & 0.028 & 0.012 & 0.008 & 0.004 & \\
\hline P1 & $\begin{array}{l}\text { [Landscape } \\
\text { casbah city] }\end{array}$ & 0.178 & 0.062 & 0.046 & 0.035 & 0.014 & 0.040 & 0.019 & 0.013 & 0.005 & 0.024 & 0.044 & 0.013 & 0.008 & 0.005 & 0.024 & 0.013 & 0.023 & 0.005 & 0.017 & 0.007 & 0.005 & 0.002 & 0.603 \\
\hline P2 & $\begin{array}{l}\text { [Landscape } \\
\text { colonial city } \\
\text { within the } \\
\text { protection } \\
\text { walls) }\end{array}$ & 0.074 & 0.026 & 0.019 & 0.015 & 0.006 & 0.017 & 0.008 & 0.005 & 0.002 & 0.010 & 0.018 & 0.005 & 0.003 & 0.002 & 0.010 & 0.005 & 0.009 & 0.002 & 0.007 & 0.003 & 0.002 & 0.001 & 0.251 \\
\hline $\begin{array}{l}P \\
3\end{array}$ & $\begin{array}{l}\text { [Landscape } \\
\text { colonial city } \\
\text { historical } \\
\text { centrality] }\end{array}$ & 0.018 & 0.006 & 0.005 & 0.004 & 0.001 & 0.004 & 0.002 & 0.001 & 0.000 & 0.002 & 0.004 & 0.001 & 0.001 & 0.000 & 0.002 & 0.001 & 0.002 & 0.000 & 0.002 & 0.001 & 0.000 & 0.000 & 0.060 \\
\hline P4 & $\begin{array}{l}\text { [Landscape } \\
\text { colonial city } \\
\text { evolution of } \\
\text { heights] }\end{array}$ & 0.027 & 0.009 & 0.007 & 0.005 & 0.002 & 0.006 & 0.003 & 0.002 & 0.001 & 0.004 & 0.007 & 0.002 & 0.001 & 0.001 & 0.004 & 0.002 & 0.003 & 0.001 & 0.003 & 0.001 & 0.001 & 0.000 & 0.090 \\
\hline
\end{tabular}

Source: own study

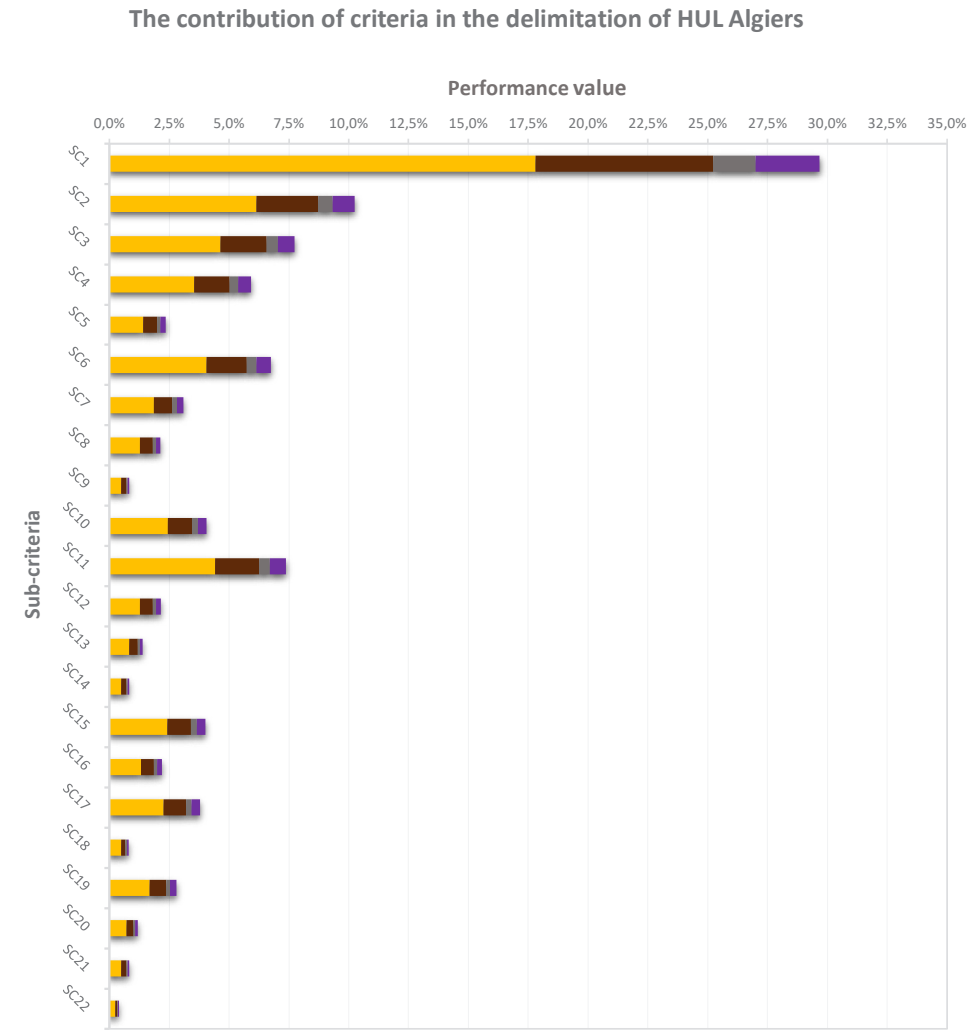

[P1]Landscape casbah city

- [P2]Landscape colonial city within the protection walls

- [P3]Landscape colonial city historical centrality

- [P4]Landscape colonial city evolution of the heights

Figure 12. Criteria contribution for the delimitation of HUL Algiers

Source: own study 


\section{Delimitation Of HUL Algiers}

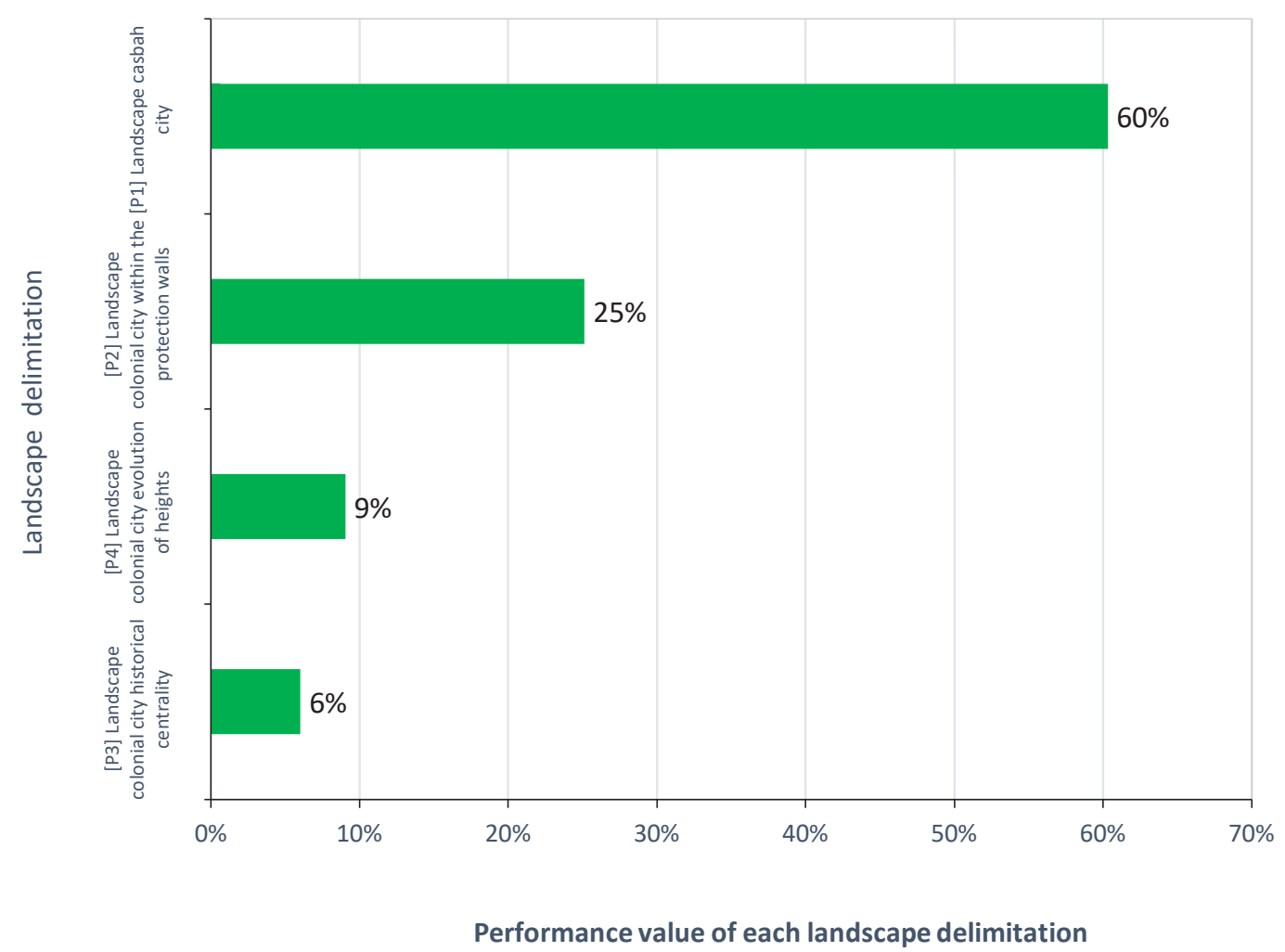

Figure 13. Delimitation of HUL Algiers

Source: own study

the nineteenth century is less efficient concerning the four alternatives, which denotes that the criteria of the configuration of the heritage system is insufficient for consideration as a global element for safeguarding historic entities in Algiers alone, without the use of the landscape.

The results obtained and illustrated in Figure 12 confirm the demarcation of the alternative P1 (medina) of the delimitation of the landscape in the historic urban area of Algiers. P2 (colonial city landscape within the protective walls) constitutes the second delimitation, which is in direct relation to $\mathrm{P} 1$ and the natural context with its sub-criteria (maritime site, configuration of the bay, port site). P4 (colonial city landscape with the evolution of the heights) is the third type of landscape because of its configuration on the heights (topography of the hills, headlands, plateaus, amphitheatre, balconies, gardens), and is directly linked to P2; while P3 (landscape of the historic centrality of the colonial city), as the fourth type of landscape, which appears between P2 and $\mathrm{P} 3$, ranks last in this evaluation and is more characterized by the dynamic role of its historic centrality, confirmed by the presence of two main historic urban axes as urban walks (Didouche Mourad \& Hassiba Benbouali), as well as by direct links with the trade port.

We therefore distinguish, in this overall evaluation, the process of using the units within the limits of the landscape. Delimiting the landscape is the means by which we preserve both the landscape and historic heritage in the context of the historic urban area of Algiers. It cannot be dissociated from the natural context, therefore, the criterion of the beauty of a site is fundamental to the definition of the overall value, as well as the criterion of the configuration of the relational system as a whole. Another finding in this paper was the degree of AHP response in the landscape assessment as a way of understanding values, and this is a testament to the effectiveness of the grouping value in characterizing the landscape configuration and then the process of its delimitation.

Although this has been an initial attempt, the exploration of the different urban landscape units (Fig 14), and the categories of value used, may be of use in others' research in defining the historic urban landscape in the whole of the historic urban area of Algiers. This evaluation, supported by the use of GIS, made it possible to clarify the different points of view about the landscape criteria that was spatially associated with the landscape elements in order to support the decision-making process for planning the various operations for safeguarding, protecting, and improving the historical urban area of Algiers as a whole in relation to its natural context.

\section{Conclusion}

This research paper has presented a process of delimiting using AHP as a connection and junction between landscape features, and then shown the importance of considering the boundaries that are urban qualities for continuity and visibility (Lynch 1969) that unify entities and preserve the values of connection. This allows decision-makers to follow a process of sustainable planning (Laprise et al. 2015) and to act in consideration of landscape values. These values must be thought of an instrument for integrating the protection of heritage and the natural environment, and to introduce it into urban planning to act together in the decision-making process by assessing the 
MISCELLANEA GEOGRAPHICA - REGIONAL STUDIES ON DEVELOPMENT

Vol. 25 • No. 2 - 2021 • pp. 110-126 • ISSN: 2084-6118 • DOI: 10.2478/mgrsd-2020-0053

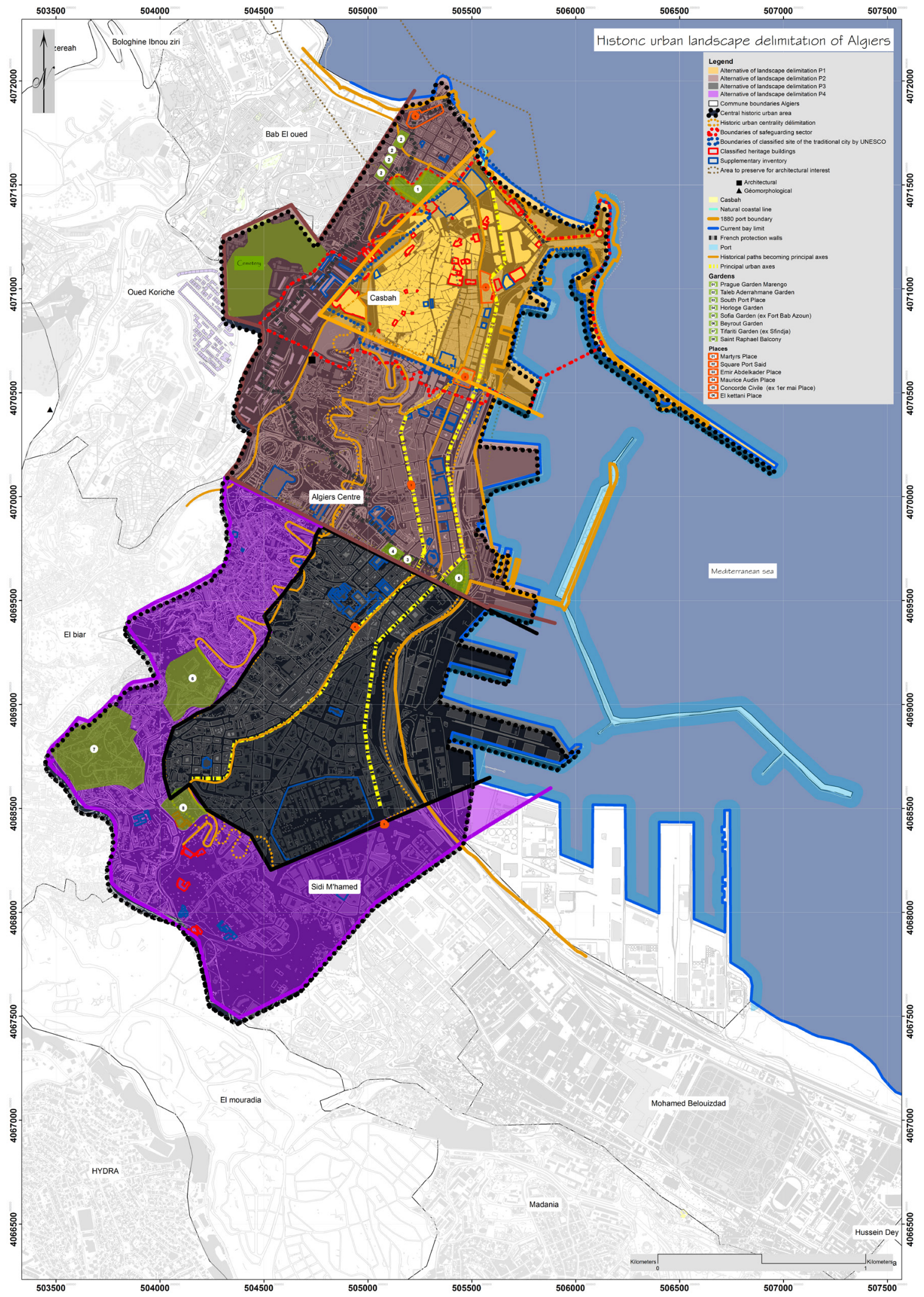

Figure 14. Map alternatives for the delimitation of HUL Algiers

Source: own study 
heritage safeguarding linked to the landscape instrument (Amato et al. 2017).

This indicates the importance of not operating across dispersed perimeters separated from their natural context and from each landscape configuration in connection with safeguarding the scenic beauty of Algiers' landscape configurations.

Historic urban landscape conservation needs models of assessment between Algiers' landscape delimitation and spatial competition to generate sustainable urban development and this constitutes a great domain of research yet to be completed.

ORCID

Boukratem Oumelkheir (10 https://orcid.org/0000-0002-9137-9225

Djelal Nadia (1D https://orcid.org/0000-0003-1350-6126

\section{References}

Amato, F, Martellozzo, F, Nolè, G \& Murgante, B 2017, 'Preserving cultural heritage by supporting landscape planning with quantitative predictions of soil consumption', Journal of Cultural Heritage, vol. 23, pp. 44-54.

Antrop, M 2004, 'Landscape change and the urbanization process in Europe', Landscape and urban planning, vol. 67, no. 1-4, pp. 9-26.

Béguin, F, Baudez, G, Lesage, D \& Godin, L 1983, Arabisances: décor architectural et tracé urbain en Afrique du Nord 18301950, Dunod, Paris.

Belton, V \& Stewart, T 2002, Multiple criteria decision analysis: an integrated approach, Springer Science \& Business Media, Boston.

Bergsten, A \& Zetterberg, A 2013, 'To model the landscape as a network: A practitioner's perspective', Landscape and urban planning, vol. 119, pp. 35-43.

Bottero, M 2011, ,Indicators assessment systems' in Landscape Indicators, vol. 7, eds C Cassatella \& A Peano, Springer, Dordrecht, pp. 15-29.

Çelik, Z 1997, Urban forms and colonial confrontation: Algiers under French rule, University of California Press, Berkley. Available from: <http://ark.cdlib.org/ark:/13030/ft8c6009jk>. [10 December 2020].

Chouquer, G 2000, L'étude des paysages : essais sur leurs formes et leur histoire, Editions Errance, France.

Cresti, F 1996, Alger au XVIlème siècle, Edition du centro analisi sociale progetti Roma, Italy.

De Noronha Vaz, E, Cabral, P, Caetano, M, Nijkamp, P \& Painho, M 2012, 'Urban heritage endangerment at the interface of future cities and past heritage: A spatial vulnerability assessment', Habitat International, vol. 36, no. 2, pp. 287294.

Dhingra, M, Singh, MK \& Chattopadhyay, S 2017, ,Macro level characterization of Historic Urban Landscape: Case study of Alwar walled city', City, Culture and Society, vol. 9, pp. 39-53.

Dobson, S 2012, ,Historic landscape characterisation in the urban domain', Proceedings of the Institution of Civil EngineersUrban Design and Planning, vol. 165, no. 1, pp. 11-19.

Finotto, F 2011, ,Landscape assessment: the ecological profile' in Landscape Indicators, vol. 7, eds C Cassatella \& A Peano, Springer, Dordrecht, pp. 47-75.

Fitri, I, Ahmad, Y \& Ahmad, F 2015, ,Conservation of tangible cultural heritage in Indonesia: a review current national criteria for assessing heritage value', Procedia-Social and Behavioral Sciences, vol. 184, pp. 71-78.

Forte, F, Girard, LF \& Nijkamp, P 2006, ,Smart policy, creative strategy and urban development', Studies in Regional Science, vol. 35, no. 4, pp. 947-963.

Gabrielli, B 2008, 'La planification urbaine à l'égard du paysage urbain historique', Culture \& Musées, vol. 11, pp. 127-134.

Garmy, P 2012, Villes, réseaux et systèmes de villes, Errance, France.
Getty Conservation Institute, 2009, Historic Cities \& Urban Settlements, Meeting report, Urban Environment: Conservation challenges and priorities for action, Los Angeles.

Gravagnuolo, A \& Girard, LF 2017, 'Multicriteria tools for the implementation of historic urban landscape', Quality Innovation Prosperity, vol. 21, no. 1, pp. 186-201.

GURA (Groupement d'urbanisme de la Région d'Alger) 1963, Plan d'Urbanisme d'Alger.

Ingold, T 1993, 'The temporality of the landscape', World archaeology, vol. 25, pp. 152-174.

Jakob, M 2004, L'émergence du paysage, InFolio Editions, Gollion, Suisse.

Jokilehto, J 2010, 'Reflection on historic urban landscapes as a tool for conservation', WHC-World Heritage Papers, no. 27, French editing: Marie Noel Tournoux, UNESCO World Heritage Centre, Paris, pp. 53-63.

Laprise, M, Lufkin, S \& Rey, E 2015, ,An indicator system for the assessment of sustainability integrated into the project dynamics of regeneration of disused urban areas', Building and Environment, vol. 86, pp. 29-38.

Layton, R \& Ucko, P 2003, The archaeology and anthropology of landscape: shaping your landscape, Routledge, London and New York.

Lespès, R 1930, Alger, étude de géographie et d'histoire urbaines, F. Alcan, Paris.

Luo, F, Liu, Y, Peng, J \& Wu, J 2018, 'Assessing urban landscape ecological risk through an adaptive cycle framework', Landscape and urban planning, vol. 180, pp. 125-134.

Lynch, K 1969, L'image de la cité, Ed. Dunod, Paris.

Missoum, S 2003, Alger à l'époque ottomane: la médina et la maison traditionnelle, Édisud, Aix-en-Provence.

Morehart, CT \& Millhauser, JK 2016, ,Monitoring cultural landscapes from space: Evaluating archaeological sites in the Basin of Mexico using very high resolution satellite imagery', Journal of Archaeological Science: Reports, vol. 10, pp. 363-376.

Nacib Y \& Icheboudene, L 1999, Paul Guion La Casbah d'Alger, Edition Publisud, Paris.

Oppio, A, Bottero, M, Ferretti, V, Fratesi, U, Ponzini, D \& Pracchi, V 2015, 'Giving space to multicriteria analysis for complex cultural heritage systems: the case of the castles in Valle D'Aosta Region, Italy', Journal of Cultural Heritage, vol. 16, no. 6 , pp. 779-789.

PAC 2006, Programme d'Aménagement côtier «Zone Côtière Algéroise», Ministère de l'Aménagement du Territoire, de l'Environnement, Alger.

PDAU 2010, Plan Directeur d'Aménagement et d'Urbanisme, Rapport stratégie et schéma d'aménagement des espaces naturels agricoles et patrimoniaux remarquables, version finale révisée, Direction d'Urbanisme d'Architecture et de construction, Alger.

PDAU 2015, Plan Directeur d'Aménagement et d'Urbanisme , Rapport d'orientation, version finale révisée, Direction d'Urbanisme d'Architecture et de construction, Alger. 
Peano, A, Bottero, M \& Cassatella, C 2011, 'Proposal for a set of indicators' in Landscape Indicators, vol. 7, eds C Cassatella \& A Peano, Springer, Dordrecht, pp. 193-215.

Phillips, A 2002, ,Management guidelines for IUCN category V protected areas: Protected landscapes/seascapes', Best Practice Protected Area Guidelines series, vol. 9, IUCN-The World Conservation Union, Cardiff.

PIPPA 2012, Plan for implementing the programme of work on protected areas of the convention on biological diversity, Ministère de l'Aménagement du Territoire et de I'Environnement (MATE), Alger.

PPSMVSS 2007, Plan Permanent de Mise en valeur du Secteur Sauvegarde de La Casbah, Groupe Centre National d'Etudes et de Recherches appliquées en Urbanisme 2007, Direction de la Culture de la wilaya d'Alger, Alger.

PUD 1987, Plan d'Urbanisme d'Alger; Orientations paysageres et Reglement, Centre National d'etudes et de recherches appliqueses en Urbanisme, Ministere de l'Amenagement du territoire de l'Urbanisme et de la construction, Alger.

Raverau, A 2007, La Casbah d'Alger, et le site créa la ville, Éditions Actes Sud Sindbad, Arles.

Richling, A, Malinowska, E \& Szumacher, I 2013, ,Delimitation of landscape units treated as estimation fields in the modelling of a landscape system', Miscellanea Geographica-Regional Studies on Development, vol. 17, no. 4, pp. 13-20.

Ruiz-Frau, A, Edwards-Jones, G \& Kaiser, M 2011, 'Mapping stakeholder values for coastal zone management', Marine Ecology Progress Series, vol. 434, pp. 239-249.

Saaty, TL 1990, 'How to make a decision: the analytic hierarchy process', European Journal of Operational Research, vol. 48, no. 1, pp. 9-26.

Saaty, TL \& Vargas, LG 2012, Models, methods, concepts \& applications of the analytic hierarchy process, Springer Science \& Business Media, Boston.

Scolozzi, R., Morri, E \& Santolini, R 2012, 'Delphi-based change assessment in ecosystem service values to support strategic spatial planning in Italian landscapes', Ecological Indicators, vol. 21, pp. 134-144.

SDAAM 2010, Schéma Directeur d'Aménagement de l'Aire Métropolitaine d'Alger, vol. N3 ressources et espaces naturels, CNERU - IAU-IDF, MATET, Alger.

SDZAH 2008, Schéma directeur des zones archéologiques et historiques, Ministère de la Culture , Alger.

SNAT 2008, Schéma National d'Aménagement du territoire, Document de synthèse, Ministère de l'Aménagement du Territoire, de l'Environnement et du Tourisme, Alger.

Tieskens, KF, Van Zanten, BT, Schulp, CJ \& Verburg, PH 2018, 'Aesthetic appreciation of the cultural landscape through social media: An analysis of revealed preference in the Dutch river landscape', Landscape and urban planning, vol. 177, pp. 128-137.

Van Oers, R 2010, Managing cities and the historic urban landscape initiative-an introduction' in WHC-World Heritage Papers, vol. 27, Managing historic cities, eds R van Oers \& S Haraguchi, UNESCO World Heritage Center, Paris, pp.7-17.

Voghera, A 2011, 'Land use indicators for landscape assessment', in Landscape Indicators, vol. 7, eds C Cassatella \& A Peano, Springer, Dordrecht, pp. 141-165.

Volpiano, M 2011, 'Indicators for the assessment of historic landscape features', in Landscape Indicators, vol. 7, eds C Cassatella \& A Peano, Springer, Dordrecht, pp. 77-104.

Zetterberg, A, Mortberg, UM \& Balfors, B 2010, 'Making graph theory operational for landscape ecological assessments, planning, and design', Landscape and urban planning, vol. 95 , no. 4 , pp. 81-191.
Zhang, Y 2011, 'Boundaries of power: politics of urban preservation in two Chicago neighbourhoods', Urban Affairs Review, vol. 47, no. 4, pp. 511-540. Available from: <http:// uar.sagepub.com/content/47/4/511>. [20 December 2020]. 